\title{
LEGAL REGULATION ISSUES OF CRYPTOCURRENCY CIRCULATION IN UKRAINE
}

\author{
Vasyl Rossikhin ${ }^{1}$ \\ Kharkiv National University of Radio Electronics, Ukraine \\ Mykhailo Burdin² \\ Kharkiv National University of Internal Affairs, Ukraine \\ Oleg Mykhalskyi $i^{3}$ \\ Kharkiv Research Institute of Forensic Examinations, Ukraine
}

\begin{abstract}
The aim of the article is a comparative legal study of laws and regulations that determine the legal principles for the regulation of cryptocurrency circulation in some foreign countries and in Ukraine and, on this basis, a definition of ways to improve domestic legislation in this sphere. The subject of the study is an interrogation of legal regulation issues of cryptocurrency circulation in Ukraine. Methodology. The study is based on a legal comparison of the regulation of cryptocurrency circulation in Ukraine and in foreign countries. Based on a comparative legal study of certain provisions of Ukrainian legislation, the possibilities and limits of implementation of positive foreign experience in this sphere are determined. The results of the study revealed that to implement foreign experience for the legal regulation of cryptocurrency circulation, it is necessary to postpone the final transition to a floating rate regime by reinforcing state interference. Moreover, it is necessary to strengthen currency control not only for currency transactions with cryptocurrency but also for the activities of entities that determine the state policy on cryptocurrency regulation, as well as operate respectively using instruments provided for by the regulations of the current legislation. Practical implications. The positive experience of the formation of the foreign exchange market in other countries demonstrates that the gradual transition to cryptocurrency circulation is the beginning of the natural market rate, the balance of payments and gradual liberation of the national economy from the pressure of administrative and corruption restrictions. Relevance/originality. The legal analysis of the regulation of cryptocurrency circulation in Ukraine and the definition of problems is the basis for developing the most promising directions for the development of domestic legislation in this sphere.
\end{abstract}

Key words: legal regulation, currency, cryptocurrency circulation.

JEL Classification: G28, F31

\section{Problem statement}

The scientific and ideological basis of financial law application is a conceptual component of the financial and legal policy of the state and reflects the content and main forms of law-enforcement activity considering the specificities of financial and legal relations. M.D. Hnatiuk emphasizes that implementation of the legal policy of the state is impossible without law enforcement. Outside of law enforcement, the national policy on legal regulation could not achieve any state goal, which would remain only an intention for implementation (Hnatiuk, 2007). Considering the special role of the jurisdictional bodies in financial ( $\operatorname{tax}$ ) law enforcement, as well as the public nature of financial and legal relations, it should

\footnotetext{
Corresponding author:

${ }^{1}$ Kharkiv National University of Radio Electronics.

${ }^{2}$ Kharkiv National University of Internal Affairs.

${ }^{3}$ Kharkiv Research Institute of Forensic Examinations.
}

be noted that the latter have a close connection with the financial-legal ( $\operatorname{tax})$ policy of the state, its fiscal interests. Taking into account the specificities of the current law system in the structure of legal policy, individual directions can be distinguished, such as constitutional, administrative, criminal, financial policy, etc. Each of them has its special features, for example, the activities of special subjects, tasks, and objects of political and legal influence, specific measures of such influence, etc.

\section{Literature review}

A significant contribution to the study of the legal regulation of cryptocurrency circulation in Ukraine 
was made by foreign and domestic scientists, such as E.M. Ashmaryna, O.L. Valevskyi, M.D. Hnatiuk, P.M. Godme, S.P. Zakharchenkov, A.I. Zemlyn, M.V. Karaseva, A.N. Kozyryn, V.M. Oparin, V.M. Fokin. The aim of the article is a comparative legal study of laws and regulations that determine the legal principles for the regulation of cryptocurrency circulation in some foreign countries and in Ukraine and, on this basis, a definition of ways to improve domestic legislation in this sphere.

\section{The main material}

It is common knowledge that financial law depends on policy and its significant manifestations. M.V. Karaseva argues that financial law, like any other branch of law, is a political phenomenon. Furthermore, she specifies that policy is obligatory for the formation of any regulations. Law is the most effective guide to the policy. She argues that there are no apolitical branches of law from the perspective of forming regulations and implementing present policies. By nature, financial policy is a type of state policy (Karaseva, 2002). O.M. Ashmarina states that financial policy is an independent activity of the state in financial relations and differentiates a financial strategy (development of the main directions of the use of finance, forms and types of financial relations) and financial tactics (solving specific economic tasks of a certain stage of state development by applying the necessary means and forms of financial relations) (Ashmarina, 2011). O. Valevskyi notes that state policy is problem solutions by state authorities that contribute most effectively to the realization of the interests of society. He interprets state policy as an activity aimed at solving problems of social development. According to O. Valevskyi, the main thing in policy implementation is the definition of the essence of the problem to be solved by the intervention of state authorities (Valevskyi, 2001). Therefore, social development is a key factor in forming a state policy.

Analysing the impact of policy on finance, P.M. Godme states that this impact can be considered from two perspectives. On the one hand, the relationship between political forces and the political structure of a country largely determines the financial policy of this country. On the other hand, political events, especially a crisis, also affect public finances and set up a financial mechanism going (Godme, 1978). According to V.M. Fokin, at the macroeconomic level, fiscal policy, which includes tax regulation, serves to manage demand and stabilize prices and industrial production (Fokin, 2004).

According to O. Kozyrin, tax policy is a part of the general financial policy and is the subject of the study of economic science. The connection of tax policy with law manifests itself, first of all, in two directions: a) by tax policy the main objectives of taxation are implemented, therefore, its study explains better the subject of regulation by tax law; $b$ ) the tax policy provides for tax reforms that are executed by corresponding financial laws (Kozyrin, 1993). O.I. Zemlin argues that tax policy is the main instrument of state regulation of the economy, because of a financial influence on entrepreneurship. Such an effect connotes the following objectives of the state: sustainable economic growth; the stability of prices for basic goods and services; full employment of the able-bodied population, the minimum level of incomes, etc. (Zemlin, 2005).

Conceptual provisions, guidelines, forms, methods of enforcement are the basis of financial and legal policies. S. P. Zakharchenkov states that public finance policy is an important and integral part of the economic policy of the state revealed in the laws regulating financial relations. Specific laws reflect the abstract idea of how to distribute and redistribute financial resources to achieve the goal (Zakharchenkov, 2008). The financial and legal policy includes the budget policy implementation in the state; moreover, some provisions are in Monetary Policy Guidelines for the relevant year. They are official documents, approved by the resolutions of the Verkhovna Rada of Ukraine and reflected in the Law of Ukraine "On the State Budget of Ukraine" for the relevant year. In addition, the financial and legal policy is implemented in tax policy consistent with the provisions of the Verkhovna Rada of Ukraine "On Tax Policy in Ukraine and Measures to Improve Tax Legislation" (Verkhovna Rada of Ukraine, 1999), monetary policy (Monetary Policy Guidelines for the current year), etc.

According to economist V. Oparin, financial policy is a complex of actions and measures carried out by the state within the limits of its functions and powers in financial activity of economic entities and financial institutions, citizens and the state to solve certain problems and achieve the goals set. In his opinion, the financial policy of the state includes a monetary (a set of actions and measures in the sphere of the money market) and fiscal policy. The latter is divided into tax (the state's activities in the field of taxation, provision of types and the ratio of taxes, identification of payers and approaches to them (unified or differentiated), tax rate establishment, provision of tax benefits, etc.) and budget (formation of the state budget, its balancing, distribution of budget funds, etc.) (Oparin, 2002).

The existence and specificity of financial and legal policy, provided for in the rules of financial law and implemented in law enforcement actions, are caused by: the need for effective implementation of the will of the legislator considering actual problems of implementation of their tasks and functions by the state and local self-government bodies; interests of the state in rational development of applying financial law.

Financial and legal policy, as well as the entire state policy, is characterized by an administrative influence on social relations. Its formation is the prerogative of the subjects of state power (the Verkhovna Rada of Ukraine, the Cabinet of Ministers of Ukraine, etc.). 
The quality of financial and legal policy implementation depends on the current system of tax administration provided for by the Tax Code of Ukraine. To be precise, strong organizational structures, procedures, systems of relations should be formed so that payers of taxes and fees could execute their rights and obligations efficiently and competently. Then it is possible to increase the effectiveness of tax policy. Therefore, the content of financial and legal policy in the application of the rules of law should be considered in the following areas.

First, the leading principles of financial and legal policy, implemented in law enforcement, are provided by the highest state authorities and must consider the situation and prospects of socio-economic, political development. It is well-known that changes in tax and budget laws are often the result of political debate and mass protests (for example, public demonstrations at the Independence Square regarding the procedure for tax control after the adoption of the Tax Code of Ukraine). Professor S.V. Kurylev formulates the dependence of law enforcement on the socio-political situation in the state from the perspective that enforcement, although determined by various factors, largely depends on the content of regulations. This study supports his position. Moreover, the scientist expresses correctly and precisely, almost in aphoristic form, that economy defines the policy, policy defines legal consciousness, legal consciousness defines law, the content of law defines the activity of law enforcement bodies (Kurylev, 1965).

It should be noted that the need for legal enforcement is caused by the very nature of the state. Law enforcement helps to implement the rules of law into life, set them going, and apply them to different life cases. The legal framework of financial and legal policy, implemented in law enforcement activities, is provided for, first of all, in the Constitution of Ukraine and laws adopted on its basis. The scientific and doctrinal component of financial policy, implemented in law enforcement activities, includes the scientific substantiation and legislative provision of the bases of applying financial law regulations, functioning in the system of measures for ensuring the interests of the state, defining legal grounds, forms of law enforcement activities considering the features of social relations, the system of subjects with operative and supervisory (regulatory) and jurisdictional authorities, their tasks, competencies, principles of interaction. Financial and legal policy, provided for in regulations and implemented in lawenforcement activities, is the most important link between the practice of applying the financial law and law-making activity of the state ensuring their unity and interaction in legal regulation.

It is important that, at the present stage, the level of qualification of potential subjects of law enforcement is problematic. It is well known that the ultimate result of financial and legal influence depends on the quality and correctness of enforcement. A law enforcer must have a high level of managerial culture, necessary and sufficient knowledgeinlawand otherspheres ofscientificknowledge. In applying the financial law, conflicts, inaccuracies, and difficulties arise often, therefore, law enforcers (other subjects) are involved in the interpretation of the rules of financial law, consequently, the authorized agents make corresponding decisions (law enforcement acts, court decisions, etc.). That is why, on the one hand, the priority tasks of financial and legal policy in this direction should be the principle of professionalism at all levels of the state apparatus, engaged in power realization of financial and legal regulations, increase of social status of subjects of law enforcement, socio-economic and political and legal guarantees of their activities. On the other hand, one of the areas of financial and legal policy should be an increase of the competence and responsibility of individuals in the legislative process concerning the requirements of law and order of law, the introduction of an effective system of operational consultations of state bodies, etc.

Nowadays, the cryptocurrency market in Ukraine is in the so-called "grey zone," because no regulation provides for the rules for its functioning, rights and obligations of participants in cryptocurrency transactions and tax rates.

In 2014, the National Bank of Ukraine identified Bitcoin as a money surrogate that had no real value and could not be used by individuals or legal entities as a means of payment. Then there was a silence for three years. Nevertheless, in 2017, the authorities had to return to this issue. After a series of publications in the mass media and an expanded discussion, the National Bank of Ukraine had to explain what kind of legal status Bitcoin had in our country. However, this explanation was reduced to the acknowledgement of their uncertainty on the issue and obligation to determine it in the near future.

The National Bank of Ukraine stated that at the moment Bitcoin did not have a certain legal status in Ukraine. The definition of such a status is complicated by the lack of a consolidated approach to the classification of Bitcoin and the regulation of agreements with it in the world.

Two draft laws are being considered by the Verkhovna Rada of Ukraine. The first and the main one is No. 7183 as of October 06, 2017, according to which the cryptocurrency is recognized as a program code (a set of symbols, numbers, and letters) that is the object of property rights, which can act as a means of exchange, the information about which is entered and stored in the blockchain system as the accounting units of the current block system in the form of data (program code). If this draft law is adopted, an individual engaged in "mining" will have to pay $18 \%$ tax on personal income and $1.5 \%$ of military gathering to the state. However, this document does not specify from what sum to calculate tax and at what rate to determine the tax base, because the quotes of cryptocurrency change every second. Using common regulations of private property the subject of cryptocurrency transactions can carry out 
transactions for the exchange of one cryptocurrency for another, exchange for electronic money, currency values, securities, services and goods. It is also proposed to allow cryptocurrency exchange in Ukraine.

Another Draft Law No. 7183-1 as of October 10, 2017, provides for the definition of cryptocurrency as a decentralized digital value measurement that can be denominated in numerical form and functions as a means of exchange, a store of value or a unit of account, which is based on mathematical calculations being their result and has cryptographic protection of accounting. The authors of the Draft Law No. 7183-1 on October 10,2017 , offer to consider cryptocurrency a financial asset for legal regulation.

An alternative approach to regulation of cryptocurrency transactions is to recognize "mining" (creating cryptocurrency) as a business operation category, that is, an activity classified by NACE-2010 class 63.11, namely, data processing, information placement on websites and related activities.

The above will enable individuals involved in mining to engage legally in economic activity by the main activity class 63.11 QWEAL-2010, and the state - to receive income in the form of taxes from the operations of creation, sale, and purchase of cryptocurrency.

In addition, according to the current tax legislation, when establishing a particular tax, it is mandatory to determine such elements as:

- taxpayers;

- the object of taxation;

- tax base;

- tax rate;

- tax calculation procedure;

- tax period;

- tax payment term and procedure;

- the term and procedure for reporting on the calculation and payment of tax.

If for any reason, this or that item is not set, the tax is considered not to be set.
Therefore, first, the state must determine what cryptocurrency, in general, and Bitcoin, in particular, are in Ukraine, and second, indicate how to pay taxes on cryptocurrency transactions and necessarily define the elements of tax that will then be collected in the state.

Negative averment on cryptocurrency by financial regulators means that in case of virtual asset impairment, the state has no mechanisms for investors to compensate cash losses, as it happens with bank deposits or other financial instruments. According to the authorities, the risks of using cryptocurrency in Ukraine may also be related to tax legislation and the lack of proper judicial protection of participant interests in cryptocurrency transactions

The unregulated status of cryptocurrencies in Ukraine does not allow legal entities to participate in transactions with them. Accounting and tax compliance are impossible for such assets. For any accountant, this operation is extremely risky, because the lack of a normative definition of "cryptocurrency" leads to uncertainty of correct entering corresponding transactions into financial statements, and consequently, to errors in taxation and determination of tax liabilities. In the future, it may cause tax deductions and problems for the entity.

\section{Conclusions}

The absence of legal regulation on cryptocurrency complicates protecting the rights of cryptocurrency holders in the courts. According to some court decisions, Bitcoin has not been recognized as goods or property rights to the entries in the open database of Blockchain and determined as an object that cannot be subject to legal protection at all and cannot be claimed by enforcement.

Therefore, under current economic conditions in Ukraine, it is urgent to legalize the circulation of cryptocurrencies in the domestic market and to create a legal framework for state regulation of economic relations on their basis, as well as entrepreneurial activity.

\section{References:}

Hnatiuk M.D. (2007). Pravozastosuvannia ta yoho mistse v protsesi realizatsii prava [Law enforcement and its place in law realization] (Dissertation of $\mathrm{PhD}$ in specialty 12.00.01.), $211 \mathrm{p}$. (in Ukrainian)

Karaseva M.V. (Ed.) (2002). Finansovoe pravo Rossiiskoi Federatsii: Uchebnyk [Financial Law of the Russian Federation: A teaching manual]. M.: Yurist, 576 p. (in Russian)

Ashmarina E.M. (2011). Nekotorye osobennosti predmeta, metoda pravovogo regulirovaniia y otdelnykh norm sovremennogo finansovogo prava [Some features of the subject, the method of legal regulation and individual norms of modern financial law]. Gosudarstvo i pravo [State and Law], 3, 16-23. (in Russian)

Valevskyi O.L. (2001). Derzhavna polityka v Ukraini: metodolohiia analizu, stratehiia, mekhanizmyvprovadzhennia [State policy in Ukraine: methodology of analysis, strategy, implementation mechanisms] (Monography). K.: NISR, 242 p. (in Ukrainian)

Godme P.M. (1978). Finansovoe pravo [Financial Law]. M.: Progress, 428 p. (in Russian)

Fokin V.M. (2004). Nalogovoe regulirovanie: ucheb. posobie [Tax regulation: A teaching manual]. S.G. Pepeliaev (Ed.). Moscow: Statut, 297 p. (in Russian)

Kozyrin A.N. (1993). Nalogovoe pravo zarubezhnykh stran: voprosy teorii y praktiki [Tax law of foreign countries: issues of theory and practice]. M.: Manuscript, 112 p. (in Russian) 
Zemlin A.I. (2005). Nalogovoe pravo: uchebnik [Tax law: A teaching manual]. M.: FORUM: INFRA-M, 304 p. (in Russian)

Zakharchenkov S.P. (2008). Finansy: UA [Finances: UA] (2nd ed.). Kh.: Factor, 92 p. (in Ukrainian)

Verkhovna Rada of Ukraine (1999). Pro podatkovu polityku v Ukraini ta zakhody shchodo udoskonalennia podatkovoho zakonodavstva [On tax policy in Ukraine and measures to improve tax legislation] (Resolution no. 641-XIV of May 12, 1999). Vidomosti Verkhovnoi Rady Ukrainy [Bulletin of the Verkhovna Rada of Ukraine], 27, 222. (in Ukrainian)

Oparin V.M. (2002). Finansy: (Zagalna teoriia): navch. posib. [Finances: (General theory): A teaching manual] (2nd ed.). K.: KNEU, 240 p. (in Ukrainian)

Kurylev S.V. (1965). Sovershenstvovanie zakonodatelstva kak uslovie strogogo sobliudeniia printsipa sotsialisticheskoi zakonnosti [Improving legislation as a condition for strict compliance with the principle of socialist legality]. Izvestiia vysshikh uchebnykh zavedenii [Bulletin of Higher Educational Institutions], 4, 18. L.: Publishing House of Leningrad University. Pravovedenie [Jurisprudence]. (in Russian) 